\title{
Cultural transmission and correlational selection in Late Period projectile points from the Puna of Salta, Argentina (CE 900 - 1500)
}

\author{
Maria Varde , Hernán J. Muscio \\ Instituto de Arqueología, Facultad de Filosofía y Letras, Universidad de Buenos Aires. \\ National Scientific and Technical Research Council - CONICET. Buenos Aires, Argentina. \\ Email: Varde: mariavardeh@gmail.com; Musico: hmuscio@gmail.com
}

\begin{abstract}
:
This work proposes a methodology for documenting metric patterns of variation and trait correlation in Late Period (ca. CE 900-1500) projectile points from the Puna and pre-Puna of Salta, Argentina. In so doing, our main goal is to explain the patterns observed in terms of mechanisms of cultural evolution and selection over the design of the artefacts. We applied this methodology to assemblages of concave-based triangular projectile points from four archaeological sites whose chronologies are well established. As a result, we were able to document low degrees of variation, as well as high, positive, significant, Pearson co-variation and partial correlation coefficients between metrical traits. These results suggest a process of correlational selection that preserved an artefact design with a structure of highly integrated traits that maximised the edge-area in relation to the haft, turning these projectile points into very lethal weapons, even for potential use in interpersonal violence. This lends support to the hypothesis presented here, where replication of these projectile points occurred within a process of stabilizing cultural selection through biased transmission mechanisms that maintained the functional relations between the variables at the design scale, which in turn favoured the selection of artefacts suitable for effective weapons in a context where hunting was a strategy that optimized animal biomass acquisition, enhancing domestic herd viability.
\end{abstract}

Keywords: evolutionary archaeology; cultural transmission; highlands of Salta; projectile points; metric variation

\section{Introduction}

During the last 300 years before European contact, a particular type of lithic projectile point predominated in Northwest Argentina: concave-based triangular points (Figure 1). These artefacts had bifacial or unifacial reduction and marginal retouch along the edges, and were made from fine-grained raw materials. This concave-based triangular design was found all over Northwest Argentina, from the mesothermal valleys to the high altitude Puna across the modern-day Provinces of Jujuy, Salta and Catamarca. Use of this projectile point reached

Published by the School of History, Classics and Archaeology, University of Edinburgh ISSN: 2055-0472. URL: http://journals.ed.ac.uk/lithicstudies/ 
its dominance in the assemblages during the second half of the Late period (CE 1200-1500) (Álvarez 2004; Ávalos 2002; Ávalos 2003; Carbonelli 2012; 2014; Chaparro 2009; 2010; Chaparro \& Avalos 2014; Elías 2007; 2010; 2012; Escola et al. 2006; Flores \& Wynveldt 2009; Gaál 2011; 2014; Lavallée et al. 1997; Ledesma 2003; Leoni et al. 2014; López et al. 2015; Muscio \& Varde 2015; Olivera \& Grant 2009; Ratto 2003b; Sprovieri 2007; Williams 2003; Yacobaccio et al. 2011). Furthermore, this morphological type was found in other regions of Argentina, such as Cuyo, Patagonia and Sierras Centrales (Balena et al. 2018; Nami et al. 2015; Revuelta 2009).

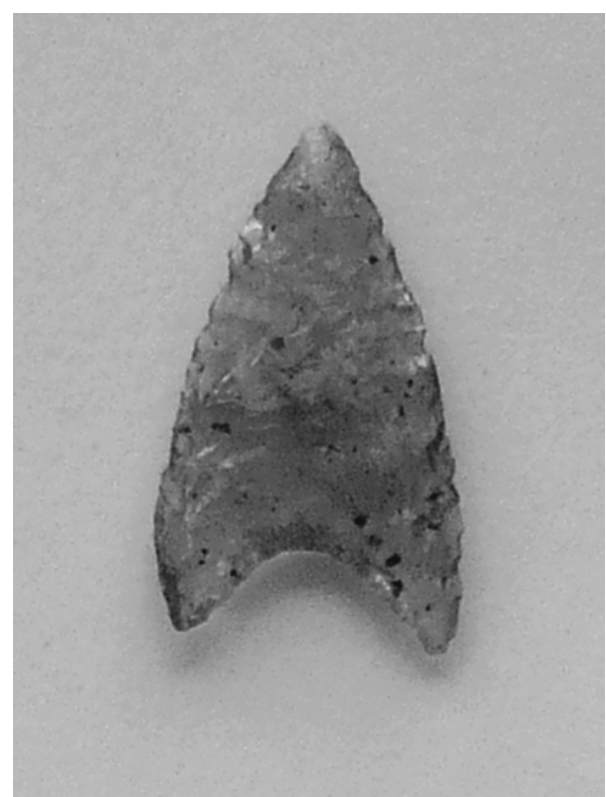

Figure 1. An example of an obsidian concave-based triangular projectile point from Cueva Nacimiento 1, Salta Province, Argentina.

The appearance of the concave-based triangular points in the archaeological record was related to the introduction of a new hafting technology that required a change in the stem of the point to form a basal concavity (Ávalos 2002). This projectile point design show a certain homogeneity in form and the frequent use of non-local obsidian for their manufacture (Álvarez 2004; Ávalos 2002; Ávalos 2003; Chaparro 2009; 2010; Chaparro \& Avalos 2014; Elías 2010; 2012; Flores \& Wynveldt 2009; Gaál 2014; Ledesma 2003; Sprovieri 2007). However, with very few exceptions (Ledesma 2003; Muscio \& Varde 2015; Varde 2017), specific and detailed analysis of metric and formal variation of the points have not been undertaken. This is the aim of this article. Below, we present a methodology for recording the variation and co-variation of metric variables on projectile points. The assemblages studied herein date to the Late Period and are geographically from the Puna and pre-Puna of Salta, Argentina. Based on these analyses, we can then hypothesise concerning the role played by transmission mechanisms acting during the replication of these technologies within a wider process of stabilizing cultural selection.

\subsection{Theoretical background}

Evolutionary studies of the archaeology of the Puna of Salta, Argentina, has witnessed growth over the last few decades (Azcune \& Gomez 2002; Cardillo 2002; 2005; 2009; Coloca 2017; Hoguin \& Restifo 2012; López 2009a; Mercuri 2011; Muscio 2004; Muscio \& Cardillo 2016; Muscio \& López 2011; Muscio \& López 2009; Restifo 2013; Varde 2017). This research agenda has integrated different evolutionary approaches, such as the human 
behavioral ecology (Smith 2000), the theory of cultural transmission (Boyd \& Richerson 1985), and the so-called evolutionary archaeology (O'Brien \& Lyman 2000). Here we contribute to this line of research through the application of a methodology especially designed for analysing variation, while applying the theory of cultural transmission and cultural selection. Our case-study analyses variation in the lithic points of the Puna and prePuna of Salta Late Period in Argentina.

During the Late Period, camelid hunting was documented at several highland archaeological contexts. This contextual archaeological evidence was of two types, zooarchaeological evidence of wild camelids, and the presence of projectile points used as hunting weapons (Albeck \& Ruiz 2003; Angiorama 2011; Grant \& Escola 2015; Izeta 2008; López et al. 2015; Mercolli 2010; Mercolli \& Nielsen 2013; Moreno 2011; Nielsen 2003; Olivera \& Grant 2008; Olivera \& Grant 2009; Olivera 1997; Raffino et al. 1977; Ratto 2003a; Tarragó 2000; Varde et al. 2017; Yacobaccio et al. 1998; Yacobaccio et al. 2011). This evidence demonstrates that during the Late Period, hunting was an important and enduring economic strategy that was employed even when pastoralism was well developed in the region. Moreover, it has been argued that hunting was a means of optimising animal biomass production for human consumption, given that it allowed for preservation of the domesticated herd (Muscio \& Varde 2015). From an adaptive viewpoint, several authors have emphasised the functional relationship between the economic strategies of human groups and their lithic technologies (Goodale \& Andrefsky 2015). On this basis, and without disregarding the possible use of these projectile points as weapons in interpersonal conflict, we propose that the pressures towards greater efficiency and effectiveness in the hunting of wild camelids provided the evolutionary context for the continued development of this technology.

\subsubsection{Designs as units for the evolutionary analysis of artefacts.}

Researchers have affirmed that culture evolves in a similar manner to biology, given that like biological evolution, cultural evolution implies a system of inheritance at the population level (Eerkens \& Lipo 2005; 2007; Mesoudi et al. 2006). In this framework, two main mechanisms of cultural evolution have been highlighted. On the one hand, under a mechanism of guided variation, new cultural variants are created and tested via experimentation, and retained by social learning. So, the general outcome of this process is an increase in variation within the cultural pool. On the other hand, under a mechanism of biased transmission, one existing cultural variant is favoured over others through social learning, leading to a variability decrease within the cultural pool (Boyd \& Richerson 1985; Durham 1991; Eerkens \& Lipo 2007). Furthermore, biased transmission is a cultural selection process, which we would expect to happen whenever the cost of error in an adaptive response is high (Boyd \& Richerson 1985; Durham 1991; Eerkens \& Lipo 2005; Muscio 2009; Richerson \& Boyd 1992; Shennan 2002).

Within this analysis framework, various evolutionary researchers referred to "recipes" as “(...) behavioral information that can be transmitted between people about how to produce something that may or may not leave a material trace (...) the recipe concept behaviorally links two general structures - ingredients and rules - that can be reconfigured to form different recipes and thus different products (...)” (O’Brien, Lyman, Mesoudi, and Van Pool 2010: 3802). Artefacts are the product of cultural information that is preserved across generations within a population through the transmission of recipes, and its evolution occurs due to the two mechanisms indicated above (Boyd \& Richerson 1985; Durham 1991; Eerkens \& Lipo 2007).

In addition, artefacts have a structure that renders them able to perform certain functions, such as being utilitarian and/or symbolic (Schiffer 2010). We term this: its design. From this 
perspective, the design is the organizational unit of an artefact that confers its functional integrity and that results from the application of a recipe. It is at this level where we would expect transmission and selection to act on the design of the artefact through replicative differentials (Neff 2001).

From a structural point of view, the artefact design may include both, packages of correlated traits, and more varyingly autonomous traits. This correlation of traits results from correlational selection, which preserves optimal co-variation of traits for a particular function. This is known as "phenotypic integrity" (Goswami \& Polly 2010). Therefore, the design has sufficient structural integrity (Pocklington \& Best 1997). This structural integrity means that component features cooperate with each other at a larger unit of scale. In this manner, artefact evolution can be explained by understanding the processes whereby novel variation in recipes is introduced resulting in new designs, complemented by the selection of certain particular designs over others. The theory of cultural transmission was developed to model these processes of cultural evolution in terms of biased and unbiased mechanisms (Boyd \& Richerson 1985; Richerson \& Boyd 2004).

In applying the cultural transmission framework to archaeological projectile point assemblages, Bettinger and Eerkens (1997; 1999) showed that as long as biased transmission acted on a dataset, variation decreased due to a lesser degree of guided variation action, and of other mechanisms that introduced variation. This is precisely what Boyd and Richerson (1985) predicted when modelling the two general mechanisms by which culture evolves. Also, Bettinger \& Eerkens (1999) proposed that the hallmark of biased transmission particularly indirect bias - was the correlation of artefact traits. This is because they assumed that variation was transmitted in packages of traits taken from successful social role-models (Bettinger \& Eerkens 1997; Bettinger \& Eerkens 1999; Boyd \& Richerson 1985; Eerkens \& Lipo 2005; 2007; Lyman et al. 2008).

Alternatively, we propose that cultural evolution can also proceed through the selection of artefact designs with optimal combinations of some of its traits (correlational selection). On this basis, we built a methodology that took into consideration the fact that artefact designs (and not just role-models) can be the focus of biased transmission mechanisms and replication. More specifically, we propose that the designs of the artefacts can be replicated through recipes that integrate packages of correlated traits and traits that vary more autonomously. In this way, the role of biased transmission is to selectively preserve optimal designs with such a structure of traits integration. Moreover, the preservation of the correlation between traits in artefact designs can be the result of stabilizing selection. By stabilizing selection, we refer to the selection process acting against extreme values of traits at the population level, which in turn produces a persistence of low levels of variation. In turn, this has also been used to explain stasis in morphological designs (Lieberman \& Dudgeon 1996) and trait combinations in genetics as result of correlational and stabilizing selection (Johnson \& Barton 2005).

Therefore, our methodology seeks to document the correlation and variation between the metric traits of projectile points. Our hypothesis is that during the Late Period the need for efficiency in hunting led to a process of stabilizing cultural selection that favored optimal designs of projectile points that decreased the failure during hunting. Furthermore, the information related to the replication of these artefacts was mostly transmitted in packages of traits, thereby helping to maintain optimal designs. 


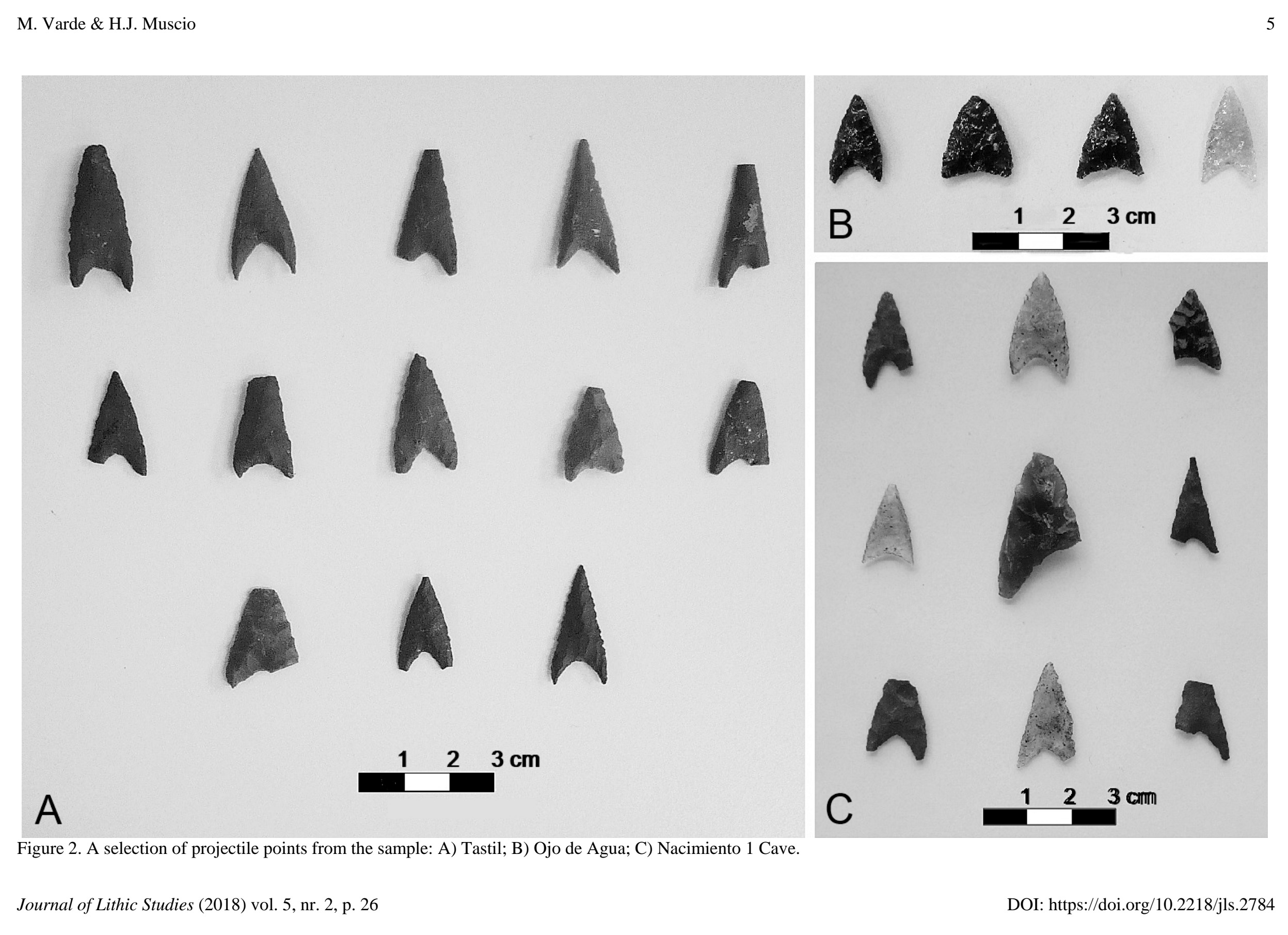




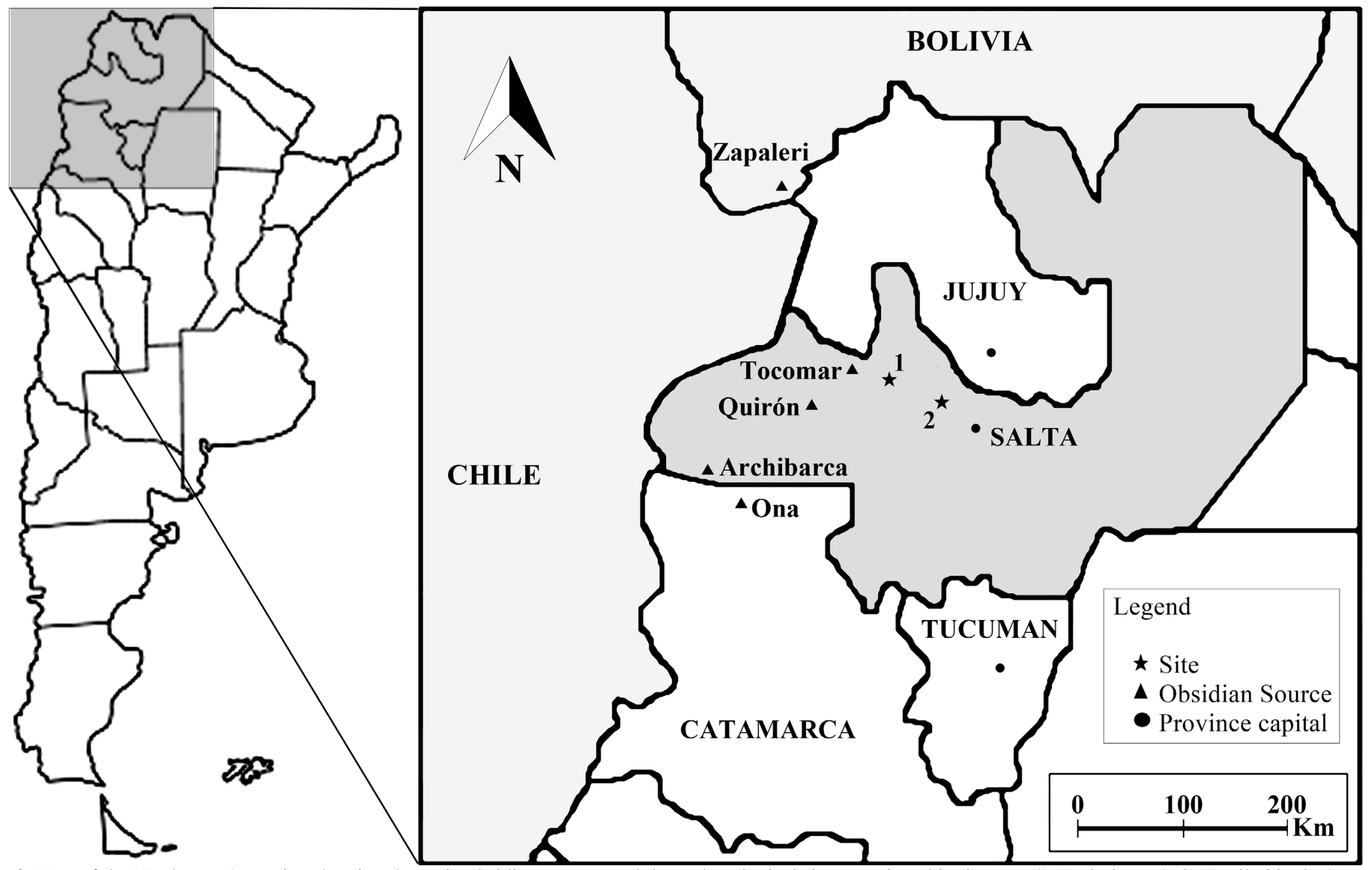

Figure 3. Map of the Northwest Argentina showing the main obsidian sources and the archaeological sites mentioned in the text: 1) Nacimiento 1;2) Tastil, Ojo de Agua and Kilómetro 15. 


\section{Materials and methods}

The analysed assemblage consisted of a set of concave-based triangular projectile points (Figure 2) obtained from four sites with well-established archaeological contexts and radiocarbon dates, these are: Tastil, Cueva Nacimiento 1, Ojo de Agua, and Kilómetro 15 (Figure 3). Insofar as broken points were concerned, we only analysed those that had a broken tip or barbs, which allowed us to reconstruct their form, and so measure their metric variables. Those points which were too broken or reused were not used in this study. At the end, sample size was of 44 points. For each specimen, six (6) metric variables were measured using a calliper in order to record metric variation and covariation patterns (Figure 4). We used the Coefficient of Variation (CV), to measure the amount of variation in each metric trait. This consists of the standard deviation expressed as a percentage of the mean, and it offers a standardized value, useful for the comparison of different datasets (Vaughan 2001).

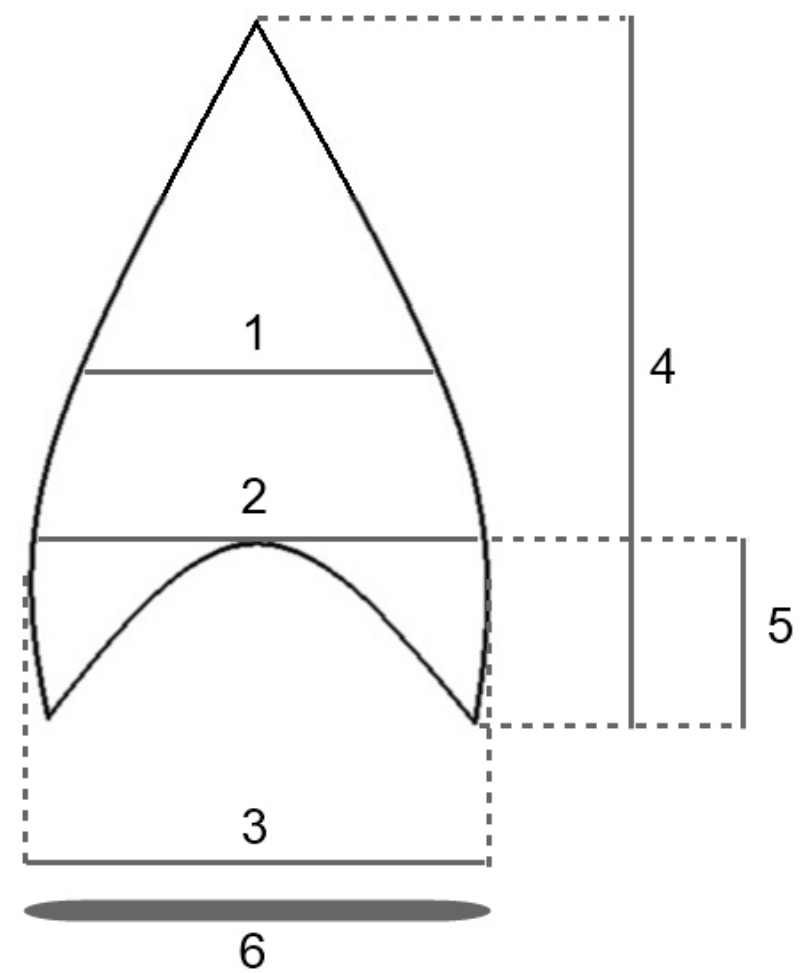

Figure 4. Metrical variables used for variation analysis: 1: Mid-width; 2: Width at the concave base; 3 : Maximum width; 4: Length; 5: Concavity depth; 6: Thickness.

To assess the whole variation within the assemblage, we calculated the confidence intervals of each CV through resampling by using PAST (Hammer et al. 2001) and running it 10,000 times. As a result, we obtained a graph for each CV as observed in the sample, coupled with its respective confidence interval at 95\%. This allowed us to compare each CV against the Averaged Coefficient of Variation (ACV) calculated as the mean of all the variation coefficients of the metric variables. ACV is important for documenting the degree of transmission homogeneity biases across the variables.

Eerkens (2000) suggests that CVs in the range of 2.5/4.5 \% are typical of the minimum error individuals make during manual production of artefacts, if they do not use external rulers. Eerkens and Bettinger (2001), suggested a theoretically derived value of $C V=57.7 \%$ as the baseline standard for random production of artefacts among humans. Variation above this figure suggests intentional introduction of variation by the artisans. On this basis, we used 
an ordinal scale between these two limits to assess the amount of variation within the dataset (Table 1).

Table 1. Ordinal scale for the amount of variation within the dataset.

\begin{tabular}{ll}
\hline CV & Level of Variation \\
\hline $0-5$ & Standardization \\
$5.1-31.35$ & Low \\
$31.36-57.7$ & High \\
$57.8-100$ & intentional introduction of variation \\
\hline
\end{tabular}

To analyse the covariation between pairs of traits, we used the Pearson Correlation Coefficient (R), considering only p-values less than 0.05 . For interpreting the magnitude of the correlations, we followed the Cohen scale (1988) which establishes that correlation coefficients in the order of 0.10 are "small," those of 0.30 are "medium", and those of 0.50 are "large" in terms of effect size magnitude (Table 2)

Table 2. Ordinal scale for the degree of the correlation between pairs of metrical traits.

\begin{tabular}{ll}
\hline PC & Degree of Correlation \\
\hline $0.1-0.3$ & Small \\
$0.3-0.5$ & Medium \\
$0.5-1$ & Large \\
\hline
\end{tabular}

In order to identify the degree to which the correlations between pairs of variables were influenced by the variation of the other variables, we used partial correlation analysis. Partial correlation is a method for identifying the correlation between two variables, with the effects of a third variable being constant (Brown \& Hendrix 2014). By this method, the variables correlated in relation with a third variable are expected to show a low or insignificant partial correlation coefficient. Conversely, the variables with the highest coefficients of partial correlation are those that correlate well and are less affected by the variance of a control variable. Hence, using this this procedure we could identify packages and pairs of correlated variables in the design of the projectile points, and the variables with a high degree of influence on the correlation matrix. To ease interpretation of the relationships between variables, we made a table that shows the different effects of each control variable in each pair of observed variables.

Finally, in order to record the lithic raw materials used in the manufacture of these artefacts and their provenance, a characterization of the rocks using chemical and petrographic analyses was generated. In assessing sourcing distances, we considered a distance of twenty-five kilometres as the limit between local and non-local sources (López 2009b).

\section{Results}

The results of the raw material analysis showed that all the projectile points in the sample were made from good quality raw material: obsidian, green silica, and aphanitic andesite (Figure 5). These are rocks with a very fine grain and conchoidal fracture. Some of the obsidian in the assemblage is from sources located at more than two hundred kilometres from the sites, such as the Zapaleri and Ona sources (Figure 3). In sum, the use of these rocks shows a strong preference for high quality materials in the manufacture of this design of projectile points, even when these materials came from very distant sources. 


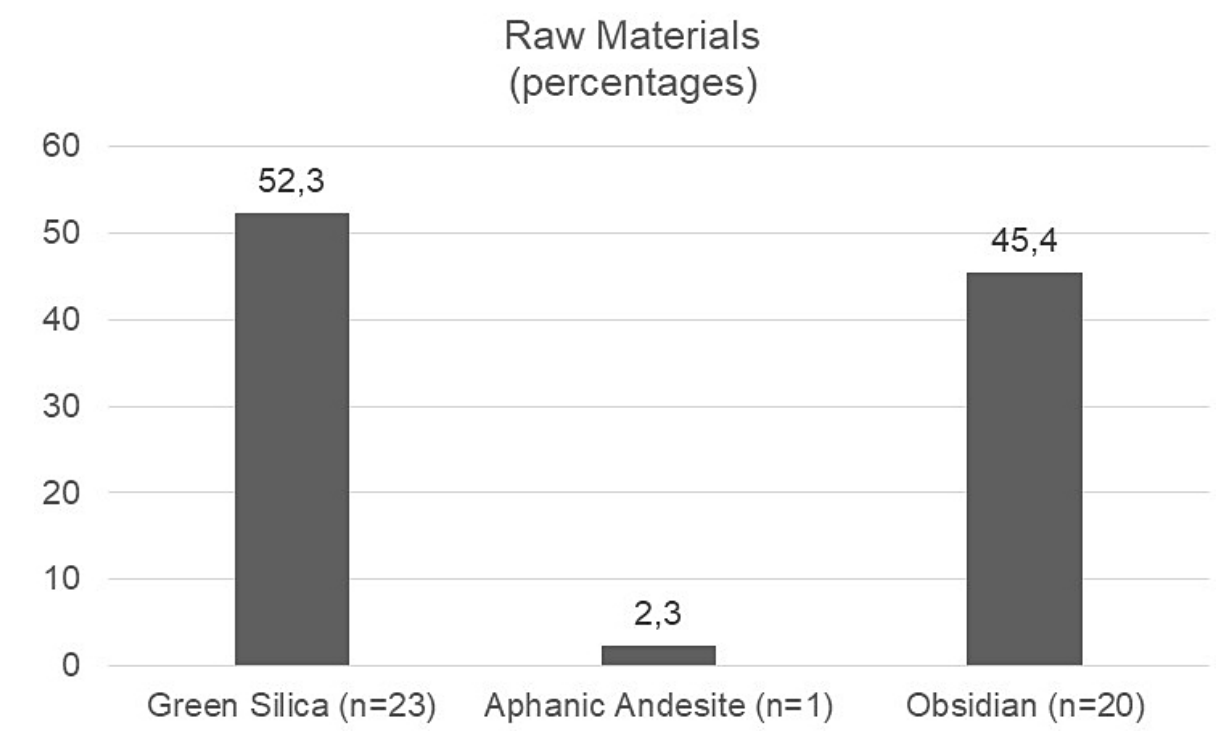

Figure 5. Percentages of the different lithic raw materials in the sample.

Regarding the degree of variation within the dataset (Table 3, Figure 6), with the exception of the concavity depth, the metrical traits show low amounts of variation measured by the CV. Also, the overall variation shown by the distribution of the CVs around the ACV indicates that when we consider the confidence intervals for each variable, the variation in the sample is not homogeneous. In fact, while the concavity depth is the trait with greatest variation, the maximum width and the width at the concave base have the lowest variation, and the rest of the variables remain close to the average CV of $19.8 \%$. We propose that this low level of variation in these two width traits could be explained by a strong replication bias towards maintaining regularity of the hafting system.

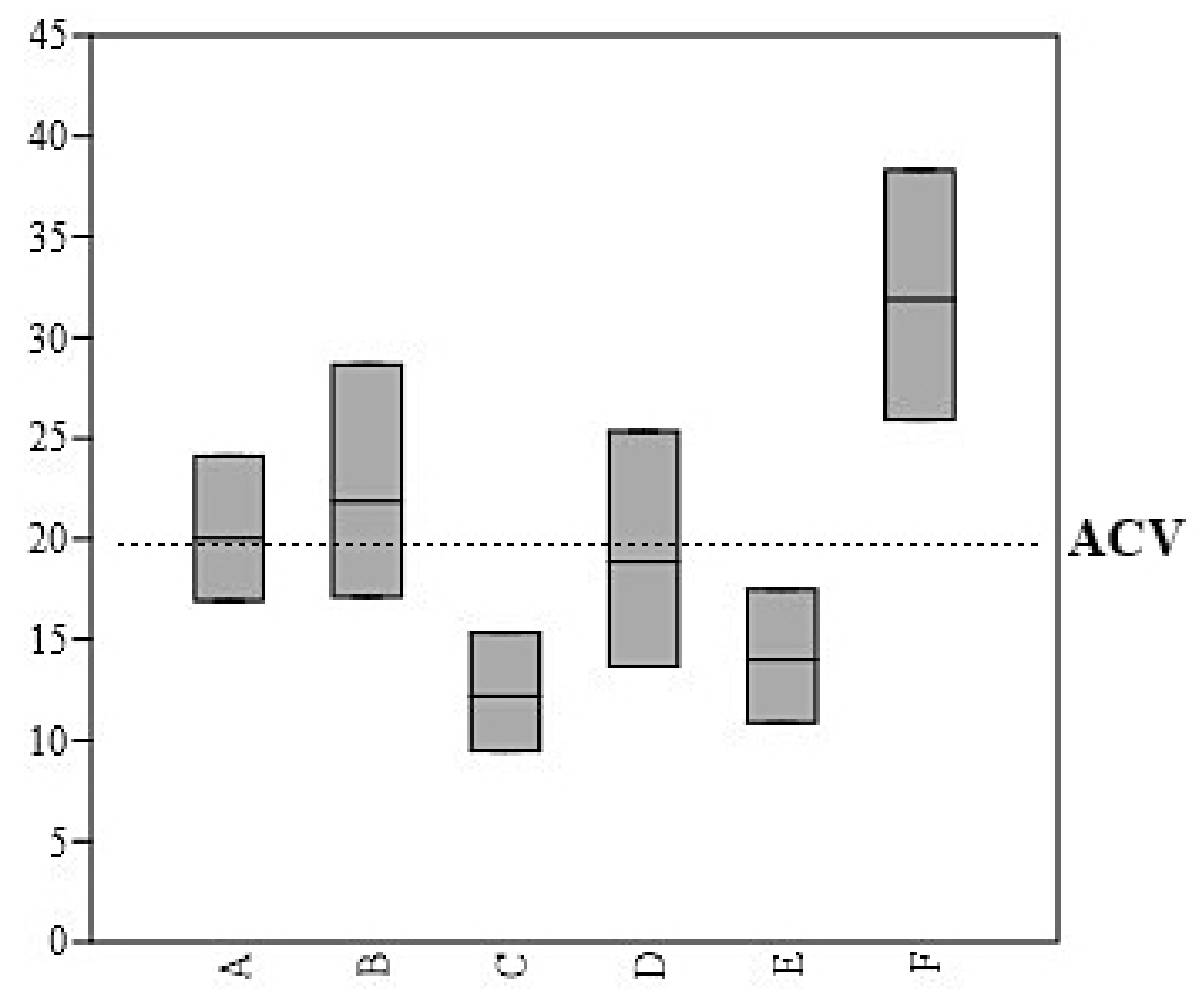

Figure 6. Boxplot of the six metric variables of the dataset with the average of the variation coefficients (ACV) (dotted line). A: length; B: thickness; C: maximum width; D: mid width; E: width at the concave base; F: concavity depth. 
Table 3. Dataset with the statistics summary

\begin{tabular}{|c|c|c|c|c|c|c|}
\hline Specimen & Length & Thickness & $\begin{array}{c}\text { Maximum } \\
\text { width }\end{array}$ & Mid-width & $\begin{array}{l}\text { Width at the } \\
\text { concave base }\end{array}$ & $\begin{array}{c}\text { Concavity } \\
\text { depth }\end{array}$ \\
\hline 1 & 38.7 & 5.3 & 14.4 & 11 & 14 & 5.7 \\
\hline 2 & 30.5 & 3.5 & 15 & 10.8 & 14.2 & 7.9 \\
\hline 3 & 35.9 & 3.1 & 13.7 & 10 & 13.5 & 7.9 \\
\hline 4 & 32.6 & 3.7 & 14.7 & 7 & 13.4 & 5.3 \\
\hline 5 & 37.4 & 3.3 & 12.2 & 8 & 12 & 8.4 \\
\hline 6 & 23.7 & 2.4 & 13.3 & 10 & 12.9 & 5.1 \\
\hline 7 & 27.3 & 3.5 & 14.4 & 10.8 & 14 & 4.9 \\
\hline 8 & 26.3 & 4.8 & 13.6 & 10 & 13.4 & 3.8 \\
\hline 9 & 25.2 & 3.9 & 14 & 8.5 & 12.9 & 4.4 \\
\hline 10 & 28.5 & 2.9 & 13.6 & 9.4 & 13.4 & 6.5 \\
\hline 11 & 26.5 & 3.1 & 16.7 & 11.6 & 16.5 & 3.5 \\
\hline 12 & 25 & 2.8 & 12.3 & 10 & 12 & 6.2 \\
\hline 13 & 26.7 & 3 & 12.6 & 8.4 & 12.2 & 5 \\
\hline 14 & 25.6 & 4 & 13.7 & 9 & 13.2 & 4.3 \\
\hline 15 & 25.5 & 3.3 & 12.4 & 9 & 12.4 & 5.7 \\
\hline 16 & 23.9 & 2.8 & 13.2 & 8.7 & 12.4 & 4.5 \\
\hline 17 & 31.6 & 2.9 & 12.9 & 10.4 & 12.5 & 8.1 \\
\hline 18 & 30.4 & 3.5 & 13.4 & 10.7 & 12.9 & 6.6 \\
\hline 19 & 30.5 & 3 & 15.2 & 11.5 & 14.7 & 4.9 \\
\hline 20 & 29.4 & 2.8 & 14.5 & 12 & 14.3 & 7 \\
\hline 21 & 25 & 2.7 & 12.8 & 8.7 & 12.2 & 6.4 \\
\hline 22 & 21.3 & 2.6 & 12 & 12.6 & 15.7 & 4.3 \\
\hline 23 & 24 & 3.3 & 15.3 & 12.2 & 15.2 & 5 \\
\hline 24 & 20.1 & 3.1 & 12.6 & 9.4 & 12.6 & 3.7 \\
\hline 25 & 18.8 & 3.5 & 16 & 12.5 & 16 & 1.5 \\
\hline 26 & 20 & 3.5 & 15.2 & 10.5 & 14.6 & 2.8 \\
\hline 27 & 21.5 & 3.2 & 12.5 & 10 & 12 & 4 \\
\hline 28 & 20.8 & 3.3 & 10.8 & 9.3 & 10.6 & 3 \\
\hline 29 & 30.2 & 3.4 & 15 & 11.2 & 14.5 & 5.2 \\
\hline 30 & 34 & 4.8 & 15.5 & 10.5 & 14.5 & 6.2 \\
\hline 31 & 22 & 2.5 & 11.5 & 8.5 & 11 & 6.1 \\
\hline 32 & 24.44 & 3 & 13 & 11 & 13 & 4.9 \\
\hline 33 & 18 & 2 & 13 & 9.5 & 13 & 3.1 \\
\hline 34 & 21 & 3 & 9.5 & 10 & 9.5 & 5.9 \\
\hline 35 & 17.5 & 3 & 12 & 8.5 & 11 & 3.1 \\
\hline 36 & 37 & 5.2 & 18.5 & 16 & 19 & 7.9 \\
\hline 37 & 23 & 2.8 & 11 & 12.5 & 10 & 3.1 \\
\hline 38 & 27.5 & 3 & 13.5 & 10 & 13.5 & 9 \\
\hline 39 & 31 & 3 & 14 & 17.5 & 12 & 7.5 \\
\hline 40 & 22 & 2 & 12.5 & 9 & 11 & 5 \\
\hline 41 & 25 & 2.9 & 13 & 8 & 11 & 5.9 \\
\hline 42 & 23 & 3 & 13 & 9.5 & 11 & 6.1 \\
\hline 43 & 30 & 2.8 & 15.3 & 11.9 & 15.3 & 8 \\
\hline 44 & 25 & 3 & 12 & 9.7 & 12 & 6.9 \\
\hline Mean & 26.44 & 3.23 & 13.53 & 10.35 & 13.11 & 5.46 \\
\hline St.Dev. & 5.30 & 0.71 & 1.65 & 1.95 & 1.83 & 1.74 \\
\hline $\mathrm{CV}$ & 20.03 & 21.87 & 12.20 & 18.86 & 13.99 & 31.91 \\
\hline $\mathrm{ACV}$ & 19.81 & & & & & \\
\hline
\end{tabular}


As Table 4 shows, we can see four variable pairs with statistically significant, large Pearson correlation values. These variable pairs are: length - concavity depth (A-F), length thickness (A-B), maximum width - width at the concave base (C-E) and the mid-width - width at the concave base (D-E). These results demonstrate the existence of significant correlation between the design variables. We can see this more consistently when we analyse the results of partial correlation.

Table 4. R of Pearson for all the pairs of variables with p-values. Highlighted in grey all the coefficients with pvalues of less than 0.05 .

\begin{tabular}{lcc}
\hline Pair of variables & R & P-value \\
\hline Length - Thickness & 0.53 & 0.00 \\
Length - Maximum Width & 0.46 & 0.00 \\
Length - Mid-width & 0.23 & 0.13 \\
Length - Width at the concave base & 0.38 & 0.01 \\
Length - Concavity depth & 0.69 & 0.00 \\
Thickness - Maximum Width & 0.49 & 0.00 \\
\hline Thickness - Mid-width & 0.20 & 0.19 \\
Thickness - Width at the concave base & 0.44 & 0.00 \\
Thickness - Concavity depth & 0.04 & 0.81 \\
Max width - Mid-width & 0.47 & 0.00 \\
Max width - Width at the concave base & 0.89 & 0.00 \\
Max width - Concavity depth & 0.09 & 0.56 \\
Mid-width - Width at the concave base & 0.51 & 0.00 \\
Mid-width - Concavity depth & 0.13 & 0.42 \\
Width at the concave base - Concavity depth & 0.06 & 0.72 \\
\hline
\end{tabular}

In the partial correlation matrix of variable pairs with the control of the individual effects of each variable (Table 5, Figure 7), we find a total of 60 correlation pairs, $20 \%$ of which are high values, $1.7 \%$ are statistically significant low values, while the remaining $48.3 \%$ correspond to associations with no statistical significance. As we can see in Figure 7, the distribution of the correlation pairs and their values in respect to each individual variable, indicates an area of large and medium correlation and a level where the correlation value for these pairs is zero or insignificant. In this second case, we found that the absence of correlation between those variables is highly influenced by the action of a third variable. Indeed, when we analyse the results of the Pearson correlation, these same pairs were not correlated in a statistically significant manner. This occurs with the pairs: length - mid width and thickness - mid width across all the variables in the sample. Contrawise, there are some variables that are correlated in a significant manner only when a single third variable is controlled. This is the case for the mid width - concavity depth; width at the concave base concavity depth; maximum width - concavity depth; and thickness - concavity depth. None of these are correlated under Pearson. Of these, the last three pairs appear inversely correlated, whereas they are correlated only when the length is controlled. In sum, across the data matrix, $51.7 \%$ of the variation documents significant correlation between variables of the projectile point design. This suggests the action of biased transmission producing a high degree of correlation among several design variables. This same fact was noted in the Pearson correlation. 
Table 5. Partial correlations for all the pairs of variables controlling every single variable of the dataset. Asterisks show statistically insignificant coefficients with p-values $>0.05$.

\begin{tabular}{lcccccc}
\hline & A & B & C & D & E & F \\
\hline AB & & & 0.39 & 0.50 & 0.44 & 0.69 \\
AC & & $0.27^{*}$ & & 0.41 & $0.29^{*}$ & 0.55 \\
AD & & $0.15^{*}$ & $0.02^{*}$ & & $0.05^{*}$ & $0.20^{*}$ \\
AE & & $0.19^{*}$ & $-0.07^{*}$ & 0.31 & & 0.47 \\
AF & & 0.79 & 0.73 & 0.68 & 0.72 & \\
BC & 0.33 & & & 0.46 & $0.25^{*}$ & 0.49 \\
BD & $0.1 *$ & & $-0.04^{*}$ & & $-0.03^{*}$ & $0.20^{*}$ \\
BE & 0.30 & & $0.00^{*}$ & 0.40 & & 0.44 \\
BF & -0.53 & & $-0.01^{*}$ & $0.01^{*}$ & $0.01^{*}$ & \\
CD & $0.42^{*}$ & 0.43 & & & $0.03^{*}$ & 0.46 \\
CE & 0.87 & 0.86 & & 0.85 & & 0.89 \\
CF & -0.35 & $0.08^{*}$ & & $0.04^{*}$ & $0.09^{*}$ & \\
DE & 0.47 & 0.48 & $0.24^{*}$ & & & 0.51 \\
DF & $-0.05^{*}$ & 0.12 & $0.09^{*}$ & & $0.11^{*}$ & \\
EF & -0.30 & $0.04^{*}$ & $-0.06^{*}$ & $-0.01^{*}$ & & \\
\hline
\end{tabular}

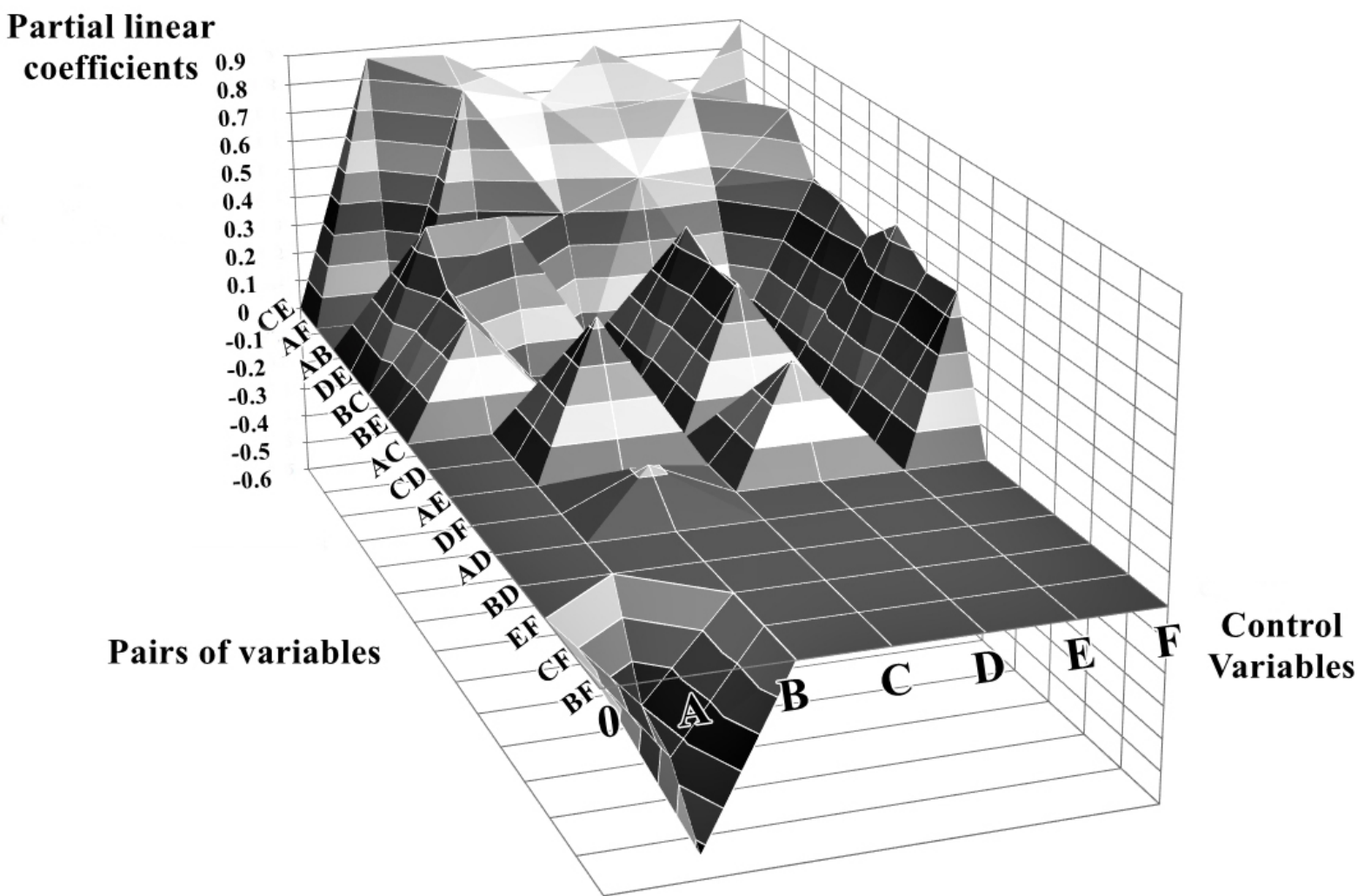

Figure 7. 3D-plot of the partial linear coefficients of the sample for every pair of variables and every control variable.

Interestingly, the two variable pairs that most co-vary independently from the rest of the variables are those related to the hafting system, given that these are the variables that give form to the basal portion of this design. These pairs are: maximum width - width at the concave base, with values above 0.8 for each control variable, and length - concavity depth, with values close to, and above 0.7. These represent the highest distribution peaks in Figure 7. The first case could be documenting the positional dependence of the base of the concavity in 
respect to the point of maximum width within the design. In the second case, the correlation between variables must have been functional in relation to the hafting system, limiting the expansion of the concavity over the blade area. In these two pairs, we notice high correlation accompanied by low variation, although this variation was slightly higher in the concavity depth, as we saw in Table 3 and Figure 6. In the data matrix (Table 5) the variables that most affect the correlation of the rest are the maximum width and the width at the concave base, which in turn are the ones with the least variation. Therefore, as we can observe in Tables 4 and 5 and Figure 7, the variables with the lowest variation coefficients are those that pertain to the width of the specimens, which likewise show clear correlation patterns with the other variables. These also have a major influence on the correlation observed between the remaining variables. We propose that the width variables of this projectile point design are directly and strongly related to the hafting system, in such a manner that the edge-area of the blade was increased to the maximum in relation to the hafting area. We can see this in the hafted points of this type found at Tastil (Figure 8).

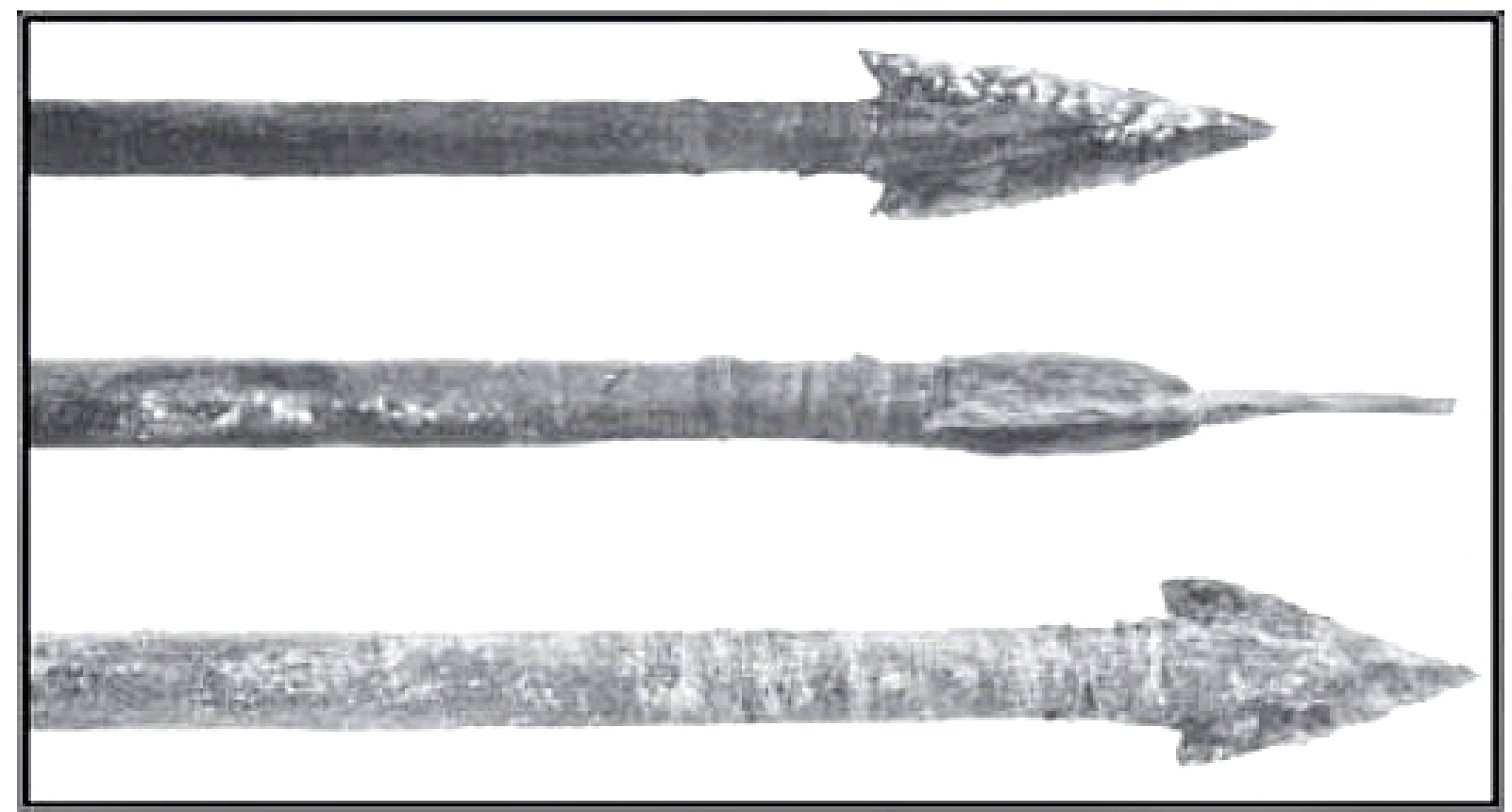

Figure 8. Arrows from the Late Period archaeological context of Tastil, Salta, Argentina (Cigliano 1973, p.197)

On the other hand, length and thickness are strongly correlated, without the influence of other variables. The interaction between length and thickness is functionally related to the size of the wound inflicted on the prey such as wider thick points inflict larger wounds that increase the bleeding (Cheshier \& Kelly 2006). Also, length and thickness are related to the potential breaking of the tool and its durability (Cheshier \& Kelly 2006). Actually, as length and thickness increase so does the lethality and the strength of the piece, until a point when these variables are optimal.

Following, the variables that appear correlated at a significant, though medium, degree, are always variables of the width. These pairs are: mid-width - width at the concave base; maximum width - thickness; and width at the concave base - maximum width. As Figure 7 shows, these correlations disappear when we introduce all the variables of the width. This means that they are not independent. For example, the pair mid width-width at the concave base shows strong correlations, but in relation with the maximum width this correlation loses statistical significance. In this sense, the width is a central variable in the design of these projectile points, a variable which interacts functionally with almost all the other variables. 
Likewise, we should highlight the strong correlation between the variables of the width and the length.

As we observe, the majority of the resulting patterns in the Pearson correlation analysis are maintained when we undertake partial correlations for each pair of variables. All this lends support to a selection process for a projectile point design with correlated traits, just as our hypothesis suggested for this concave-based triangular point design. Moreover, we document that these variables were replicated in packages, maintaining the functional relations between the variables at the design scale. This suggests selection towards optimal character combinations, or correlational cultural selection.

In this correlated variables package, the negative covariation between the concavity depth - thickness and maximum width - width at the concave base, could be explained in functional terms. As suggested by Dunnel (1978), on projectile points the presence of barbs is a functional trait that is favourably selected when there is limited necessity for removing the projectile quickly from the prey. Indeed, in our case, the size of the barb, defined by the concavity depth, increases when the projectile points become thinner and narrower. This could allow the projectile to stay stuck in the prey once impacted, and increase the lethality of thinner and narrower pieces. Indeed, this could explain the high frequency of these projectile points in the archaeological record of Cueva Nacimiento 1, as they probably were introduced into the cave inside the preys (Varde 2017). This functional hypothesis will require larger assemblages and the use of a different methodology -such as experimentation- to further prove or disprove it.

\section{Discussions and conclusions}

During the Late Period in the Argentine Puna (ca. CE 900-1500), hunting was a critical strategy for obtaining animal biomass. Along with this, the use of domesticated llama livestock, as well as trade networks, created a mixed economy which contributed to manage the risks of resource fluctuation in the Puna desert environment (Escola 2002; Hocsman \& Escola 2007; López 2002; 2003; Moreno 2011; Muscio 2004; Olivera \& Grant 2009; Yacobaccio et al. 1998).

The Puna environment is particularly hostile to llama neonates, given that these suffer a high mortality rates due to early frosts (Yacobaccio et al. 1998). Currently this situation is managed through the breeding of mixed herds of goats, sheep and llamas (Yacobaccio et al. 1998; Yacobaccio \& Vilá 2013). This solution was not available in the prehispanic past. So, whereas it is true that domesticated livestock herds were a risk-management strategy, for this strategy to work the demographic viability of the herds had to be maintained (Flannery et al. 1989; Olivera \& Grant 2009; Yacobaccio et al. 1998). Therefore, from an optimal decisionmaking viewpoint (Winterhalder \& Goland 1997), we can predict that high-ranked wild animal preys -which are production cost free- will be exploited whenever possible, thereby mitigating the need to kill members of the herd. This is crucial towards improving livestock's demographic viability. Due to this, in this paper we propose that hunting was a strategy that optimized animal biomass acquisition, as well as enhancing domestic herd viability. In turn, this led to a selective context that favoured a highly efficient and lethal projectile point design. Given that increasing hunting efficacy required reliable projectile points, cultural transmission acted selectively towards maintaining optimal character correlations, high levels of replication fidelity, and low variation patterns, as our results document.

The low metrical variation documented in our sample supports the hypothesis of high incidence of biased transmission mechanisms concerning the concave-based triangular projectile point design. This is indicative of a stabilizing selection process that acted against extreme values of the traits. Moreover, as we showed through the Pearson correlation and 
partial correlation analyses, there was significant correlation between the metrical traits of the studied design. This is the mark of transmission and replication in packages of correlated traits, and of a process of correlational selection that maintained the functional integrity of these Late Period triangular points. As we saw in the results, the variables with the least variation are those of width. In turn, these correlate well and strongly with the other variables, and at the same time affect the correlation between other metric variables. This resulted in a blade design that maximised the edge-area in relation to the haft, turning these projectile points into very lethal weapons, even for potential use in interpersonal violence. We also documented a strong preference for high quality rocks for use in reduction and retouch, shaping sharp cutting edges. As we have shown, some of these materials were sourced far from the sites analysed, and were probably obtained through trade (see obsidian sources in Figure 3).

It is important to note that these artefacts were part of a complex system, such as the bow and arrow, and that cultural selection could also have acted at this higher level. This could potentially make other traits, such as those of the haft and the bow, liable to be controlled by biased transmission. This might be exemplified by the very low variation in the maximum width of this design, where the point would have interacted with the width of the haft.

Furthermore, as we noted, this projectile point design quickly achieved a large geographical dispersion throughout Northwestern Argentina, dominating the archaeological assemblages of the Late period. As we have suggested throughout this article, this phenomenon can be explained in selective terms by taking into account the high efficacy for hunting, and probably for defence, of this design. In fact, there is ethnohistoric documentation of inter-human competition in the Calchaqui Valley, as well as archaeological rock-art scenes showing group conflicts using bows and arrows from the Argentine Puna (De Hoyos 2010; Martel 2010; Martel \& Aschero 2007). From a selective point of view, it is expectable that an advantageous trait such as this kind of artefact would spread out quickly throughout a population (Cavalli-Sforza 2001). This is why we believe that both selection and biased cultural transmission best explains the geographical dispersal and perseverance of this projectile point design throughout the Late Period. In sum, we suggest that the high degree of social interaction between distant geographical areas of Northwestern Argentina and Chile facilitated access to distant raw materials, and provided the context for the spatial dispersal of this design via mechanisms of horizontal cultural transmission and adaptive learning among groups.

\section{Acknowledgments}

Special thanks are due to our colleagues Pablo Mercolli, Silvia Soria, Claudia Macoritto and Rossana Ledesma for allowing us to use samples from their excavations in this article. The same goes for the laboratories of the Universidad Nacional de Salta (National University of Salta Province, Argentina) and the Museo de Alta Montaña (Archaeological Museum of High Mountain). We would also like to express our gratitude to María Gabriela Doña for her assistance with the Dirección General de Patrimonio Cultural de la Provincia de Salta (General Directorate of Cultural Heritage of the Province of Salta). Finally, we thank Marcelo Cardillo for his advice, as well as the editor of this journal and the anonymous reviewers of the original manuscript for their suggestions. Of course, this work would not be possible without the support of the Consejo Nacional de Investigaciones Científicas y Técnicas (National Scientific and Technical Research Council - CONICET) and the Instituto de Arqueología de la Facultad de Filosofía y Letras de la Universidad de Buenos Aires (Institute of Archeology, Faculty of Philosophy and Letters, University of Buenos Aires). 


\section{References}

Albeck, M.E. \& Ruiz, M.S. 2003, El tardío en la Puna de Jujuy: poblados, etnias y territorios. Cuadernos de la Facultad de Humanidades y Ciencias Sociales-Universidad Nacional de Jujuy, 20: 199-221. (in Spanish) ("The Late Period in the Puna of Jujuy: towns, ethnic groups and territories") URL: http://www.redalyc.org/articulo.oa?id=18502010

Álvarez, M.R. 2004, Producción lítica en el pukara de Tilcara. Mosaico. Trabajos en Antropología Social y Arqueología, 1: 25-34. (in Spanish) ("Lithic production in the Pukara of Tilcara") URL: https://www.academia.edu/1092217/

Angiorama, C.I. 2011, La ocupación del espacio en el sur de Pozuelos (Jujuy, Argentina) durante tiempos prehispánicos y coloniales. Estudios Sociales del NOA, 11: 125-142. (in Spanish) ("The occupation of space in the south of Pozuelos (Jujuy, Argentina) during prehispanic and colonial times")

URL: http://revistascientificas.filo.uba.ar/index.php/esnoa/article/view/819

Ávalos, J.C. 2002, Sistema de Producción Lítica de una Comunidad Tardía de la Quebrada de Humahuaca. Bachelor thesis at the Facultad de Humanidades y Ciencias Sociales, Universidad Nacional de Jujuy, San Salvador de Jujuy, 136 p. (in Spanish) ("Lithic Production System of a Late Community of the Quebrada de Humahuaca")

Ávalos, J.C. 2003, Sistemas de producción lítica de las sociedades tardías de la quebrada de Humahuaca. Cuadernos de la Facultad de Humanidades y Ciencias SocialesUniversidad Nacional de Jujuy, 20: 271-290. (in Spanish) ("Lithic production systems of late societes of the Quebrada de Humahuaca")

URL: https://www.researchgate.net/publication/26418923

Azcune, C. \& Gomez, M. 2002, Ecología evolutiva y estrategias reproductivas de los pastores puneños: una aproximación arqueológica. In: Perspectivas integradoras entre Arqueología y Evolución (Martínez, G. \& Lanata, J., Eds.), Instituto de Investigaciones Arqueológicas y Paleontológicas del Cuaternario Pampeano, Olavarría: p. 77-96. (in Spanish) ("Evolutionary ecology and reproductive strategies of Puna herders: an archaeological approach") URL: http://www.soc.unicen.edu.ar/arqueologia/31publicaciones.html

Balena, I., Heider, G. \& Medina, M. 2018, Tecnología lítica entre las sociedades del período prehispánico tardío (Sierras de Córdoba, Argentina). Mundo de antes, 12: 81-105. (in Spanish) ("Lithic technology among societies of the Late prehispanic period (sierras of Córdoba, Argentina)") URL: https://www.researchgate.net/publication/326377614

Bettinger, R.L. \& Eerkens, J. 1997, Evolutionary implications of metrical variation in Great Basin projectile points. In: Rediscovering Darwin: Evolutionary Theory in Archaeological Explanation (Clark, G.A. \& Barton, C.M., Eds.), Archeological Papers of the American Anthropological Association Vol. 7, American Anthropological Association, Washington D.C.: p. 177-191. doi:10.1525/ap3a.1997.7.1.177

Bettinger, R.L. \& Eerkens, J.W. 1999, Point typologies, cultural transmission, and the spread of bow-and-arrow technology in the prehistoric Great Basin. American antiquity, 64(2): 231-242. doi: $10.2307 / 2694276$

Boyd, R. \& Richerson, P.J. 1985, Culture and the evolutionary process. University of Chicago press, Chicago, $331 \mathrm{p}$.

Brown, B. \& Hendrix, S.B. 2014, Partial Correlation Coefficients. Wiley StasRef: Statistics Reference Online, 45(17): 8 p. doi:10.1002/9781118445112.stat06488 
Carbonelli, J.P. 2012, Secuencia de producción lítica en el sitio Mesada del Agua Salada, Caspinchango, Valle de Yocavil. Revista Española de Antropología Americana, 42(2): 359-382. (in Spanish) ("Sequence of Lithic Production at the Site of Mesada del Agua Salada, Caspinchango, Yocavil Valley") doi:10.5209/rev_REAA.2012.v42.n2.40110

Carbonelli, J.P. 2014, Obsidianas y puntas de proyectil: sustancia y forma de las relaciones sociales en Las Pailas, Catamarca, Argentina. Revista Colombiana de Antropología, 50(1): 117-137. (in Spanish) ("Obsidian and Projectile Points: Substance and Form of Social Relations in Las Pailas, Catamarca, Argentina") doi:10.22380/2539472X59

Cardillo, M. 2002, Transmisión cultural y persistencia diferencial de rasgos. Un modelo para el estudio de la variación morfológica de las puntas de proyectil lanceoladas de San Antonio de los Cobres, Provincia de Salta, Argentina. In: Perspectivas integradoras entre Arqueología y Evolución (Martínez, G. \& Lanata, J., Eds.), Serie teórica Vol. 1, Instituto de Investigaciones Arqueológicas y Paleontológicas del Cuaternario Pampeano, Olavarría, Argentina: p. 97-119. (in Spanish) ("Cultural transmission and differential persistence of traits. A model for the study of the morphological variation of the lanceolate projectile points of San Antonio de los Cobres, Province of Salta, Argentina")

Cardillo, M. 2005, Explorando la variación en las morfologías líticas a partir de las técnicas de análisis de contornos. El caso de las puntas de proyectil del holocenomedio-tardío de la Puna de Salta (San Antonio de los Cobres, Argentina). Werken, 7: 77-88. (in Spanish) ("Exploring the variation in lithic morphologies using contours analysis techniques. The case of projectile points of the medium-late holocen from the Puna of Salta (San Antonio los cobres, Argentina). An evolutionary approach") URL: https://www.researchgate.net/publication/275949545

Cardillo, M. 2009, Temporal trends in the morphometric variation of the lithic projectile points during the Middle Holocene of Southern Andes (Puna region). A coevolutionary approach. In: Theoretical and MethodologicalIssues in Evolutionary Archaeology. XV World Congress of the International Union for Prehistoric and Protohistoric Sciences Vol. 20 (Muscio, H.J. \& López, G., Eds.), BAR International Series Vol. S-1915, Archaeopress, Oxford: p. 13-20. (in Spanish)

Cavalli-Sforza, L.L. 2001, Genes, peoples, and languages (1 ed.). University of California Press, Berkeley, 239 p.

Chaparro, M.G. 2009, El manejo de los recursos líticos en el pasado: sociedades preestatales y estatales en el área valliserrana del Noroeste Argentino (1000-1536 DC). Unpublished $\mathrm{PhD}$ thesis at the Facultad de Filosofía y Letras, Universidad de Buenos Aires, Buenos Aires, 589 p. (in Spanish) ("The management of lithic resources in the past: pre-state and state societies in the valleys of the Argentine Northwest") URL: http://repositorio.filo.uba.ar/handle/filodigital/1859

Chaparro, M.G. 2010, La tecnología en Tolombón. Nuevas contribuciones al estudio de las sociedades tardías del NOA. Anales de Arqueología y Etnología, 63-64(2008/2009): 107-136. (in Spanish) ("The technology in Tolombón: new contributions to the study of late NOA societies") URL: https://bdigital.uncu.edu.ar/app/navegador/?idobjeto=7439 
Chaparro, M.G. \& Avalos, J.C. 2014, La tecnología lítica durante la ocupación Inka en la Quebrada de Humahuaca (Provincia de Jujuy, Argentina). In: Artefactos líticos, movilidad y funcionalidad de sitios en Sudamérica. Problemas y perspectivas (Escola, P.S. \& Hocsman, S., Eds.), South American Archaeology Series Vol. 20, Archaeopress, Oxford: p. 59-68. (in Spanish) ("The lithic technology during the Inka occupation in the Quebrada de Humahuaca (Province of Jujuy, Argentina)")

Cheshier, J. \& Kelly, R.L. 2006, Projectile point shape and durability: the effect of thickness: length. American Antiquity, 71(2): 353-363. doi:10.2307/40035908

Cohen, J. 1988, Statistical power analysis for the behavioral sciences (2 ed.). Lawrence Erlbaum Associates, New York, 567 p. URL: http://www.utstat.toronto.edu/ brunner/oldclass/378f16/readings/CohenPower.pdf

Coloca, F. 2017, Interacciones sociales, prácticas rituales y procesos de cambio durante los periodos Tardío e Inka (ca. 900-1536 DC) en la cuenca de Ratones, Puna de Salta. Unplublished $\mathrm{PhD}$ thesis at the Facultad de Filosofía y Letras, Universidad de Buenos Aires, Buenos Aires, 298 p. (in Spanish) ("Social interactions, ritual practices and processes of change during the Late and Inka periods (ca. 900-1536 AD) in the Ratones basin, Puna of Salta")

URL: https://ri.conicet.gov.ar/bitstream/handle/11336/83298/CONICET_Digital_Nro.2 452ffdf-483e-4177-8609-54539ab89b79_A.pdf

De Hoyos, M. 2010, Flechas contra la corona. Las armas reales y simbólicas en tiempos de la conquista del Noroeste. In: XVII Congreso Nacional de Arqueología Argentina Vol. 1 (Bárcena, J.R. \& Chiavazza, H., Eds.), Zeta, Mendoza, Argentina: p. 269-274. (in Spanish) ("Arrows against the crown. The real and symbolic weapons in times of the conquest of the Northwest")

Dunnell, R.C. 1978, Style and function: a fundamental dichotomy. American antiquity, 43: 192-202. doi:10.2307/279244

Durham, W.H. 1991, Coevolution: Genes, culture, and human diversity. Stanford University Press, Stanford, 629 p. URL: https://www.sup.org/books/title/?id=2588

Eerkens, J.W. 2000, Practice makes within 5\% of perfect: visual perception, motor skills, and memory in artifact variation. Current Anthropology, 41(4): 663-668. doi:10.1086/317394

Eerkens, J.W. \& Bettinger, R.L. 2001, Techniques for assessing standardization in artifact assemblages: can we scale material variability? American Antiquity, 66(3): 493-504. doi:10.2307/2694247

Eerkens, J.W. \& Lipo, C.P. 2005, Cultural transmission, copying errors, and the generation of variation in material culture and the archaeological record. Journal of Anthropological Archaeology, 24(4): 316-334. doi:10.1016/j.jaa.2005.08.001

Eerkens, J.W. \& Lipo, C.P. 2007, Cultural transmission theory and the archaeological record: providing context to understanding variation and temporal changes in material culture. Journal of Archaeological Research, 15(3): 239-274. doi:10.1007/s10814-007-9013-z

Elías, A.M. 2007, Tecnología lítica en las sociedades tardías de Antofagasta de la Sierra (Puna Meridional Argentina). Estudios atacameños, 33: 59-85. (in Spanish) ("Lithic technology in the late societies of Antofagasta de la Sierra (Puna Meridional Argentina)") doi:10.4067/S0718-10432007000100005 
Elías, A.M. 2010, Estrategia tecnológicas y variabilidad de los conjuntos líticos de las sociedades tardías en Antofagasta de la Sierra ("Provincia de Catamarca, Puna Meridional argentina). Unpublished PhD thesis at the Facultad de Filosofía y Letras, Universidad de Buenos Aires, Buenos Aires, 507 p. (in Spanish) ("Technological strategy and variability of lithic assemblages of late societies in Antofagasta de la Sierra (Province of Catamarca, Puna Meridional Argentina)")

URL: http://repositorio.filo.uba.ar/handle/filodigital/1851

Elías, A.M. 2012, Tecnología lítica en el periodo tardío (ca. 1100-550 años AP) de Antofagasta de la Sierra (Provincia de Catamarca, Puna Meridional argentina). Relaciones de la Sociedad Argentina de Antropología, 37(1): 19-41. (in Spanish) ("Late Period lithic technology (ca. 1100-550 BP) from Antofagasta de la Sierra (Province of Catamarca, southern argentine Puna)")

URL: http://www.saantropologia.com.ar/textos/tecnologia-litica-en-el-periodo-tardioca-1100-550-anos-ap-de-antofagasta-de-la-sierra-provincia-de-catamarca-punameridional-argentina/

Escola, P.S. 2002, Caza y pastoralismo: un reaseguro para la subsistencia. Relaciones de la Sociedad Argentina de Antropología, 27: 233-245. (in Spanish) ("Hunting and pastoralism: a reinsurance for subsistence")

URL: http://www.saantropologia.com.ar/textos/caza-y-pastoralismo-un-reaseguro-parala-subsistencia/

Escola, P.S., Elías, A. \& Paulides, L. 2006, Bajo del Coypar II: tendencias tecnológicas para el Tardío de Antofagasta de la Sierra (Catamarca). Werken, 8: 5-24. (in Spanish) ("Bajo del Coypar II: Technological trends for the Late period of Antofagasta de la Sierra (Catamarca)") URL: https://www.academia.edu/1449933/

Flannery, K., Marcus, J. \& Reynolds, R. 1989, The Flocks of the Wamani: A study of Llama herders on the Punas of Ayacucho, Peru. Academic Press, San Diego, 239 p.

Flores, M.C. \& Wynveldt, F. 2009, Análisis tecno-tipológico de los artefactos líticos de la Loma de los Antiguos de Azampay (Departamento de Belén, Catamarca). Intersecciones en Antropología, 10(2): 221-235. (in Spanish) ("Techno-typological analysis of the lithic artefacts of Loma de los Antiguos de Azampay(Department of Belén, Catamarca)") URL: https://www.researchgate.net/publication/48208573

Gaál, E.G. 2011, Un acercamiento preliminar al estudio de la base local de recursos líticos y al análisis artefactual en el poblado arqueológico de Rincón Chico (período Tardío), valle de Yocavil, Catamarca. Comechingonia Virtual, 5(1): 1-38. (in Spanish) ("A preliminary approach to the study of the local base of lithic resources and artefactual analysis in the archaeological town of Rincón Chico (Late period), Yocavil valley, Catamarca") URL: https://rdu.unc.edu.ar/handle/11086/5134

Gaál, E.G. 2014, Decisiones tecnológicas y producción lítica en el sur del valle de Yocavil (Pcia. de Catamarca). Un estudio comparativo de conjuntos artefactuales tempranos y tardíos. Unpublished Bachelor thesis at the Facultad de Filosofía y Letras, Universidad de buenos Aires, Buenos Aires, 304 p. (in Spanish) ("Technological decisions and lithic production in the south of the Yocavil valley (Province of Catamarca). A comparative study of early and late artefact assemblages")

Goodale, N. \& Andrefsky, W. (Eds.) 2015, Lithic technological systems and evolutionary theory, (1 ed.). Cambridge University Press, New York, 297 p. 
Goswami, A. \& Polly, P.D. 2010, Methods for studying morphological integration and modularity. The Paleontological Society Papers, 16: 213-243. doi:10.1017/S1089332600001881

Grant, J. \& Escola, P.S. 2015, La persistencia de un modo de producción doméstico durante el período Tardío: el caso de Corral Alto (Antofagasta de la Sierra, Argentina). Estudios Atacameños, 51: 99-121. (in Spanish) ("The persistence of a mode of domestic production during the Late Period: the case of Corral Alto (Antofagasta de la Sierra, Argentina)") doi:10.4067/S0718-10432015000200007

Hammer, Ø., Harper, D.A.T. \& Ryan, P.D. 2001, PAST: paleontological statistics software package for education and data analysis. Palaeontologia electronica, 4(1): 9. URL: http://palaeo-electronica.org/2001_1/past/issue1_01.htm

Hocsman, S. \& Escola, P.S. 2007, Inversión de trabajo y diseño en contextos líticos agropastoriles (Antofagasta de la Sierra, Catamarca). Cuadernos del Instituto Nacional de Antropología y Pensamiento Latinoamericano, 21(2006/2007): 75-90. (in Spanish) ("Work investment and design in agro-pastoral lithic contexts Antofagasta de la Sierra, Catamarca)")

URL: https://revistas.inapl.gob.ar/index.php/cuadernos/issue/viewIssue/Cuadernos\%20n \%2021/CUADERNOS\%20INAPL\%2021.PDF

Hoguin, R. \& Restifo, F. 2012, Patterns of Cultural Transmission in the Manufacture of Projectile Points: Implications for the Early Settlement of the Argentine Puna. Current Research in the Pleistocene., special edition: 69-74.

URL: https://www.researchgate.net/publication/285775505

Izeta, A.D. 2008, Late Holocene camelid use tendencies in two different ecological zones of Northwestern Argentina. Quaternary International, 180(1): 135-144. doi:10.1016/j.quaint.2007.08.026

Johnson, T. \& Barton, N. 2005, Theoretical models of selection and mutation on quantitative traits. Philosophical Transactions of the Royal Society B: Biological Sciences, 360(1459): 1411-1425. doi:10.1098/rstb.2005.1667

Lavallée, D., Julien, M., Karlin, C., García, L.C., Fontugne, M. \& Possi-Escot, D. 1997, Entre desierto y quebrada. Primeros resultados de las excavaciones realizadas en el abrigo de Tomayoc (Puna de Jujuy, Argentina). Bulletin de l'Institut Français d'Études Andines, 26(2): 141-175. (in Spanish) ("Between desert and valley. First results of the excavations carried out in the Tomayoc shelter (Puna of Jujuy, Argentina)") URL: https://www.researchgate.net/publication/26430999

Ledesma, R.E. 2003, Diseño de puntas de proyectil. Una vía de análisis alternativo para el estudio de identidad en la Quebrada del Toro, provincia de Salta, Argentina. Cuadernos de la Facultad de Humanidades y Ciencias Sociales-Universidad Nacional de Jujuy, 20: 241-269. (in Spanish) ("Projectile points design. An alternative way of analysis for the study of identity in Quebrada del Toro. Province of Salta, Argentina")

URL: http://www.redalyc.org/articulo.oa?id=18502012

Leoni, J.B., Fabron, G., Tamburini, D.S., Hernández, A. \& Brancatelli, C.G. 2014, "Cóndor 2", un sitio del período de Desarrollos Regionales 1 en el sector norte de la quebrada de Humahuaca, Jujuy. Estudios Sociales del Noa: nueva serie, 13: 125-145. (in Spanish) ("'Condor 2", a site from the Desarrollos regionales 1 period in the northern sector of the Quebrada de Humahuaca, Jujuy")

URL: http://revistascientificas.filo.uba.ar/index.php/esnoa/article/view/534 
Lieberman, B.S. \& Dudgeon, S. 1996, An evaluation of stabilizing selection as a mechanism for stasis. Palaeogeography, Palaeoclimatology, Palaeoecology, 127(1-4): 229-238. doi:10.1016/S0031-0182(96)00097-1

López, G.E.J. 2002, Análisis de conjuntos arqueofaunísticos del periodo Formativo de la Puna de Salta: aportes teóricos para el caso de Matancillas 2. Unpublished Bachelor thesis at the Facultad de Filosofía y Letras, Universidad de Buenos Aires, Buenos Aires, 130 p. (in Spanish) ("Analysis of archaeofaunal assemblages of the Puna Formative Period of Salta: theoretical contributions for the case of Matancillas 2")

URL: http://repositorio.filo.uba.ar/xmlui/handle/filodigital/9861

López, G.E.J. 2003, Pastoreo y caza de camélidos en el Temprano de la Puna de Salta: Datos osteométricos del sitio Matancillas 2. Intersecciones en Antropología, 4: 17-27. (in Spanish) ("Herding and hunting of camelids in the Early Puna of Salta: osteometric data from the Matancillas 2 site")

URL: http://www.scielo.org.ar/scielo.php?script=sci_arttext\&pid=S1850373X2003000100002

López, G.E.J. 2009a, Arqueofaunas, osteometría y evidencia artefactual en Pastos Grandes, Puna de Salta: secuencia de cambio a lo largo del Holoceno temprano, medio y tardío en el sitio Alero Cuevas. Intersecciones en antropología, 10: 105-119. (in Spanish) ("Archaeofaunal, osteometrical and artefactual evidence in Pastos Grandes, puna of Salta: The sequence of change through the early, middle and late Holocene in Alero Cuevas site") URL: https://www.ridaa.unicen.edu.ar/xmlui/handle/123456789/1275

López, G.E.J. 2009b, Diversidad arqueológica y cambio cultural en Pastos Grandes, puna de Salta, a lo largo del Holoceno. Relaciones de la Sociedad Argentina de Antropología, 34: 149-175. (in Spanish) ("Archaeological diversity and cultural change at Pastos Grandes, Puna of Salta, during the Holocene")

URL: http://www.saantropologia.com.ar/textos/diversidad-arqueologica-y-cambiocultural-en-pastos-grandes-puna-de-salta-a-lo-largo-del-holoceno/

López, G.E.J., Coloca, F., Araya, S., Orsi, J.P. \& Seguí, S. 2015, El sitio cueva Inca Viejo, salar de Ratones, puna de Salta: evidencia arqueológica y procesos de interacción macrorregional. Relaciones de la Sociedad Argentina de Antropología, 40: 45-71. (in Spanish) ("The Cueva Inca Viejo site, Salar de Ratones, Puna de Salta: Archaeological evidence and processes of macro-regional interaction")

URL: http://www.saantropologia.com.ar/textos/el-sitio-cueva-inca-viejo-salar-deratones-puna-de-salta-evidencia-arqueologica-y-procesos-de-interaccionmacrorregional/

Lyman, R.L., VanPool, T.L. \& O'Brien, M.J. 2008, Variation in North American dart points and arrow points when one or both are present. Journal of Archaeological Science, 35(10): 2805-2812. doi:10.1016/j.jas.2008.05.008

Martel, Á. 2010, Arte rupestre de pastores y caravaneros. Estudio contextual de las representaciones rupestres durante el período Agroalfarero Tardío (900 d.C.-1480 d.C.) en el Noroeste argentino. PhD thesis at the Facultad de Filosofía y Letras, Buenos Aires, Buenos Aires, 275 p. ("Rock art of shepherds and caravaneers: Contextual study of rock-art depictions during the Late Period (900 A.D. - 1480 A.D.) in NW Argentina") doi:10.13140/RG.2.1.2354.9680 
Martel, A. \& Aschero, C. 2007, Pastores en acción: imposición iconográfica vs. autonomía temática. In: Producción y circulación prehispánica de bienes en el sur andino (Nielsen, A.E., Rivolta, M.C., Seldes, V., Vázquez, M.M. \& Mercolli, P.H., Eds.), Brujas, Córdoba, Argentina: p. 329-349. (in Spanish) ("Pastors in action: Iconographic imposition vs. thematic autonomy")

Mercolli, P.H. 2010, Estrategias de subsistencia en la Quebrada de Humahuaca, Provincia de Jujuy. Dos casos de estudio relacionados al manejo ganadero y la trascendencia de la caza a través del tiempo en las sociedades humanas. In: Zooarqueología a principios del siglo XXI: Aportes teóricos, metodológicos y casos de estudio (Gutiérrez, M., De Nigris, M., Fernández, P., Giardina, M., Gil, A., Izeta, A.D., Neme, G. \& Yacobaccio, H.D., Eds.), Libros del espinillo, Buenos Aires: p. 273-284. (in Spanish) ("Subsistence strategies in Quebrada de Humahuaca, province of Jujuy. Two study cases related to herd management and the persistence of hunting through time in human societies") URL: http://www.repositorio.cenpatconicet.gob.ar/bitstream/handle/123456789/748/zooarqueologiaAprincipiosSigloXXI.p $\mathrm{df}$

Mercolli, P.H. \& Nielsen, A.E. 2013, Explotación faunística en el sureste de Lípez (Potosí, Bolivia) durante el Período Prehispánico Tardío. Arqueología, 19(1): 177-186. (in Spanish) ("Faunal exploitation in southeastern Lípez (Potosí, Bolivia) during the Late Prehispanic period") doi:10.34096\%2Farqueologia.t19.n1.1686

Mercuri, C. 2011, Variabilidad de Estrategias Tecnologicas Liticas durante el Periodo Formativo (ca. 2400-1400 Ap) en la Puna de Salta. Unpublished PhD thesis at the Facultad de Filosofía y Letras, Universidad de Buenos Aires, 369 p. ("Variability of Lithic Technology Strategies during the Formative Period (ca. 2400-1400 BP) in the Puna of Salta") URL: http://repositorio.filo.uba.ar/handle/filodigital/1338

Mesoudi, A., Whiten, A. \& Laland, K.N. 2006, Towards a unified science of cultural evolution. Behavioral and Brain Sciences, 29(4): 329-347. doi:10.1017/S0140525X06009083

Moreno, E.A. 2011, Tecnología de caza en la Quebrada de Antofalla, Departamento Antofagasta de la Sierra, Catamarca. Revista del Museo de Antropología, 4(1): 17-32. (in Spanish) ("Hunting technology in the Antofalla Valley, Antofagasta de la Sierra Department, Catamarca") doi:10.31048/1852.4826.v4.n1.5498

Muscio, H. 2004, Dinámica poblacional y evolución durante el período agroalfarero temprano en el Valle de San Antonio de los Cobres, puna de Salta, Argentina. Unpublished PhD thesis at the Facultad de Filosofía y Letras, Universidad de Buenos Aires, Buenos Aires, 523 p. ("Population dynamics and evolution during the early agriculturalist period in the San Antonio de los Cobres Valley, Puna de Salta, Argentina") URL: http://repositorio.filo.uba.ar/handle/filodigital/1256

Muscio, H. \& Cardillo, M. (Eds.) 2016, Darwins Legacy: The Status of Evolutionary Archaeology in Argentina, South American Archaeology Series Vol. 24. Archaeopress, Oxford, 94 p. 
Muscio, H. \& López, G. 2011, Particularidades de la arqueología de la Puna Argentina, invisibilización de su variabilidad y estado actual del conocimiento: una introducción. In: Arqueología de la Puna Argentina: perspectivas actuales en el estudio de la diversidad y el cambio cultural Vol. 2296 (Muscio, H. \& López, G.E.J., Eds.), South American Archaeology Series, Archaeopress, Oxford: p. 1-18. (in Spanish) ("Particularities of the archeology of the Puna of Argentina, invisibility of its variability and current state of knowledge: an introduction")

Muscio, H. \& Varde, M. (2015), Puntas de proyectil del período Tardío de la Cueva Nacimiento 1, Puna de Salta. Patrones de variación métrica. Instituto Interdisciplinario de Tilcara, Universidad de Buenos Aires. (in Spanish) ("Projectile points from the Late Period of the Cueva Nacimiento 1, Puna of Salta. Patterns of metric variation")

Muscio, H.J. 2009, Procesos y patrones: Una estructura evolutiva de niveles múltiples en arqueología evolutiva. In: Perspectivas actuales en arqueología argentina (Barberena, R., Borrazo, K. \& Borrero, L.A., Eds.), Instituto Multidisciplinario de Historia y ciencias Humanas, Consejo Nacional de Investigaciones científicas y técnicas, Buenos Aires: p. 215-240. (in Spanish) ("Processes and Patterns: A Structure of Multiple Levels in Evolutionary Archeology") URL: http://www.imhicihuconicet.gob.ar/html/Publ_Libros/Barberena2009Perpectactual.pdf

Muscio, H.J. \& López, G.E.J. (Eds.) 2009, Theoretical and methodological issues in evolutionary archaeology: toward an unified Darwinian paradigm, Proceedings of the XV World COngress UISPP (Lisbon, 4-9 September 2006) Vol. 20. Archaeopress, Oxford, 120 p.

Nami, H.G., Duran, V.A., Cortegoso, V. \& Giesso, M. 2015, Análisis morfológicoexperimental y por Fluorescencia de Rayos X de las puntas de proyectil de obsidiana del ajuar de Uspallata Usina Sur (Mendoza-Argentina). Boletín de la Sociedad Chilena de Arqueología, 45: 7-37. (in Spanish) ("Morphological-experimental analysis and x-ray fluorescence of the obsidian projectile points of a trousseau of the Late Agricultural Period of the NW of Mendoza, Argentina")

Neff, H. 2001, Differential persistence of what? The scale of selection issue in evolutionary archaeology. In: Style and function: Conceptual issues in evolutionary archaeology (Neff, H., Hurt, T.D. \& Rakita, G.E.M., Eds.), Bergin and Garvey, Westport: p. 25-40.

Nielsen, A.E. 2003, Ocupaciones prehispánicas de la etapa agropastoril en la Laguna de Vilama (Jujuy, Argentina). Cuadernos de la Facultad de Humanidades y Ciencias Sociales-Universidad Nacional de Jujuy, 20: 81-108. (in Spanish) ("Prehispanic occupation in the agropastoral stage at the Vilama lake (Jujuy, Argentina)") URL: http://www.redalyc.org/articulo.oa?id=18502005

O'Brien, M.J. \& Lyman, R.L. 2000, Applying evolutionary archaeology: A systematic approach (1 ed.). Kluwer Academic, Plenum Publishers, New York, 471 p. doi:10.1007/b100324

O'Brien, M.J., Lyman, R.L., Mesoudi, A. \& VanPool, T.L. 2010, Cultural traits as units of analysis. Philosophical Transactions of the Royal Society B: Biological Sciences, 365: 3797-3806. doi:10.1098/rstb.2010.0012 
Olivera, D. \& Grant, J. 2008, Economía y ambiente durante el Holoceno Tardío (ca. 4500400) de Antofagasta de la Sierra (Puna Meridional Argentina). In: Temas de Arqueología: Estudios tafonómicos y zooarqueológicos Vol. 1 (Acosta, A., Loponte, D. \& Mucciolo, L., Eds.), Fundación Amigos del Instituto Nacional de Anteropología y Pensamiento Latinoamericano: p. 99-131. (in Spanish) ("Economy and environment during the late Holocene (ca. 4500-400) of Antofagasta de la Sierra (Southern Puna of Argentina)")

Olivera, D. \& Grant, J.L. 2009, Puestos de altura de la Puna argentina: zooarqueología de Real Grande 1 y 6 y Alero Tomayoc. Revista del Museo de Antropología, 2(1): 151168. (in Spanish) ("High elevation sites of the Argentine Puna: Zooarchaeology of Real Grande 1 and 6, and Alero Tomayoc") doi:10.31048/1852.4826.v2.n1.5415

Olivera, D.E. 1997, La importancia del recurso Camelidae en la Puna de Atacama entre los 10.000 y 500 años AP. Estudios Atacameños, 14: 29-41. (in Spanish) ("The importance of Camelidae resource in the Puna of Atacama between 10.000 and 500 years before present") doi:10.22199/S07181043.1997.0014.00004

Pocklington, R. \& Best, M.L. 1997, Cultural evolution and units of selection in replicating text. Journal of Theoretical Biology, 188: 79-87. doi:10.1006/jtbi.1997.0460

Raffino, R.A., Tonni, E.P. \& Cione, A.L. 1977, Recursos alimentarios y economía de la Quebrada del Toro. Relaciones de la Sociedad Argentina de Antropología, 11: 9-30. (in Spanish) ("Food resources and economy in the region of Quebrada del Toro, Province of Salta, Argentina") URL: http://sedici.unlp.edu.ar/handle/10915/25246

Ratto, N.R. 2003a, Estrategias de caza y propiedades del registro arqueológico en la Puna de Chaschuil (Departamento Tinogasta, Catamarca, Argentina). Unpublished PhD thesis at the Facultad de Filosofia y Letras, Universidad de Buenos Aires, Buenos Aires, 338 p. (in Spanish) ("Hunt strategies and characteristics of the archaeological record in the Puna of Chaschuil (Tinogasta department, Catamarca, Argentina)")

URL: http://repositorio.filo.uba.ar/xmlui/handle/filodigital/6912

Ratto, N.R. (2003b), Tecnología de caza prehispánica en la puna de Chaschuil (Dpto.

Tinogasta, Catamarca). unpublished paper, Tucumán. 19 p. (in Spanish) ("Prehispanic Hunting Technology in the Puna of Chaschuil (Tinogasta, Catamarca)")

Restifo, F. 2013, Tecnología lítica en la puna de la provincia de Salta a lo largo del Holoceno temprano y medio: patrones de variación y procesos de cambio. Unpublished $\mathrm{PhD}$ thesis at the Facultad de filosofía y Letras, Universidad, Buenos Aires, 322 p. (in Spanish) ("Lithic technology in the Puna of the province of Salta during the early and middle Holocene: variation patterns and change processes")

URL: http://repositorio.filo.uba.ar/handle/filodigital/6017

Revuelta, C. 2009, Arqueología del Valle Vicioso: una primera aproximación a los desarrollos regionales (1000-1470 AD) en San Blas de los Sauces (Norte de La Rioja, Argentina). In: IV Jornadas Arqueológicas Cuyanas (Bárcena, J.R., Ed.), Xama Serie Monografías, Inca Editorial, Mendoza: p. 253-268. (in Spanish) ("Archaeology of the Vicioso Valley: a first approximation to the regional developments (1000-1470 AD) in San Blas de los Sauces (North of La Rioja, Argentina)")

Richerson, P.J. \& Boyd, R. 1992, Cultural inheritance and evolutionary ecology. In: Evolutionary Ecology and Human Behavior (Smith, E.A. \& Winterhalder, B., Eds.), Aldine de Gruyter, New York: p. 61-92. doi:10.4324/9780203792704 
Richerson, P.J. \& Boyd, R. 2004, Not by genes alone: How culture transformed human evolution (1 ed.). University of Chicago press, Chicago, $342 \mathrm{p}$. doi:10.7208/chicago/9780226712130.001.0001

Schiffer, M.B. 2010, Behavioral archaeology: Principles and practice. Routledge, London, 220 p. doi:10.4324/9781315541242

Shennan, S. 2002, Genes, memes, and human history: Darwinian archaeology and cultural evolution. Thames and Hudson, London, 304 p.

Smith, E.A. 2000, Three styles in the evolutionary analysis of human behavior. In: Adaptation and human behavior: An anthropological perspective (Cronk, L., Chagnon, N. \& Irons, W., Eds.), Aldin de Gruyter, New York: p. 27-46. doi:10.4324/9781351329200-3

Sprovieri, M. 2007, Producción lítica de las sociedades tardías del valle Calchaquí (Salta). Mundo de Antes, 5: 91-118. (in Spanish) ("Lithic production in Late period societies of the Calchaquí Valleys (Salta)") URL: http://www.mundodeantes.org.ar/pdf/revista5/06Sprovieri.pdf

Tarragó, M. 2000, Chacras y pukara. Desarrollos sociales tardíos. Chapter 7. In: Nueva historia argentina: Los pueblos originarios y la conquista Vol. 1 (Tarragó, M., Ed.), Editorial Sudamericana, Barcelona: p. 257-300. (in Spanish) ("Chacras and pukara. Late social developments")

Varde, M. 2017, Variación métrica en puntas de proyectil del período Tardío de la Puna de Salta y Jujuy: contribución teórico-metodológica para el estudio de transmisión cultural. Unpublished Bachelor thesis at the Facultad de Filosofía y Letras, Universidad de Buenos Aires, Buenos Aires, 206 p. (in Spanish) ("Metric variation in projectile points of the Late Period of the Puna of Salta and Jujuy: theoretical-methodological contribution for the study of cultural transmission")

Varde, M., Seguí, S. \& Rucci, L. 2017, Análisis del material arqueológico de la Cueva Nacimiento 1, Puna de Salta (Argentina), Período Tardío. Cuadernos del Instituto Nacional de Antropología y Pensamiento Latinoamericano-Series Especiales, 4(3): 3141. (in Spanish) ("Analysis of the archaeological material of Cueva Nacimiento 1, Puna of Salta (Argentina), Late Period") URL: https://ppct.caicyt.gov.ar/index.php/cinaplse/article/view/10560

Vaughan, C.D. 2001, A million years of style and function: regional and temporal variation in Acheulean handaxes. In: Style and function: conceptual issues in evolutionary archaeology (Hurt, T.D. \& Rakita, G.F.M., Eds.), Greenwood publishing group, Westport: p. 141-164.

Williams, V.I. 2003, Nuevos datos sobre la prehistoria local en la quebrada de Tolombón, Pcia de Salta, Argentina. Anales Nueva época, 6: 163-210. (in Spanish) ("New data about the local prehistory in the Quebrada de Tolombón, Salta Province, Argentina") URL: http://hdl.handle.net/2077/3257

Winterhalder, B. \& Goland, C. 1997, An Evolutionary Ecology Perspective on Diet Choice, Risk, and Plant Domestication. In: People, plants and landscapes: studies in paleoethnobotany (Gremillion, K.J., Ed.), University of Alabama Press, Tuscaloosa: p. 123-160. 
Yacobaccio, H., Madero, C.M., Malmierca, M.P. \& Reigadas, M.d.C. 1998, Caza, domesticación y pastoreo de camélidos en la Puna Argentina. Relaciones de la Sociedad Argentina de Antropología, 22-23(1997/1998): 389-428. (in Spanish) ("Hunting, domestication and herding of camelids in the Argentinian highlands") URL: http://sedici.unlp.edu.ar/handle/10915/25596

Yacobaccio, H.D., Catá, M.P., Morales, M.R., Solá, P., Alonso, M., Rosenbusch, M., Vázquez, C., Samec, C., Oxman, B. \& Cáceres, M. 2011, El uso de cuevas por pastores andinos: el caso de Cueva Quispe (Susques, Puna de Jujuy). In: Arqueología de la Puna Argentina: perspectivas actuales en el estudio de la diversidad y el cambio cultural (Muscio, H. \& López, G., Eds.), Archaeopress, Oxford: p. 33-48. (in Spanish) ("The use of caves by Andean herders: The case of Cueva Quispe (Susques, Puna of Jujuy)")

Yacobaccio, H.D. \& Vilá, B. 2013, La domesticación de los camélidos andinos como proceso de interacción humana y animal. Intersecciones en antropología, 14(1): 227-238. (in Spanish) ("The andean camelids domestication as a process of human-animal interaction") URL: http://www.redalyc.org/articulo.oa?id=179531063014 